\title{
Challenges, chances and a café: connecting with refugee English language learners
}

\section{Susan Stetson-Tiligadas}

Deree, The American College of Greece, Greece

Jane Mandalios

Deree, The American College of Greece, Greece

Keywords: Covid-19; refugee education; synchronous learning.

\section{The challenge}

Refugee learners face significant challenges to accessing educational opportunities. Some may have had their learning disrupted when they had to leave their home country, while others may not have had access to educational opportunities in their home country either. The program leaders of the MA in Teaching English to Speakers of Other Languages (TESOL) program at a Greek private college had partnered with the Greek Council for Refugees (GCR) to design and deliver English language classes for refugees taught by student volunteers from the MA TESOL program. The philosophy was to expand on services offered by the GCR through its Pyxida program, which provides Greek language classes, social support, and employment counselling to registered refugees. Five cohorts started in early 2020 in classroom spaces at the GCR in downtown Athens, allowing teachers and learners to meet twice a week, and were due to finish in April.

The first country-wide lockdown due to Covid-19 came in mid-March 2020. However, the Pyxida English classes had been designed for fully face-to-face delivery, and the collaboration had no funding, with the work being done on an entirely voluntary basis. It had already been a challenge to design a program for language learning in this under-resourced context, but when the lockdown occurred, the Pyxida English language classes were completely halted. The broader social justice issues surrounding access to technology being 
spotlighted around the world - with those who have marching on and those who have not being left behind - was playing out with the Pyxida classes, which could not easily switch to emergency remote teaching (Hodges et al., 2020) through synchronous online lessons. The English classes would need to be completely redesigned for online delivery. Consequently, no English language classes were offered in Fall 2020 for the Pyxida learners.

In December 2020, we tried to reimagine how the language learning experience could take place online given the various challenges that already existed, plus the new challenges from Covid-19. For example, data privacy issues surrounding refugee learners' personal information precluded the possibility of creating accounts, even for free LMS platforms such as Google Classroom. Also, for online learning, the learning device available to most refugee learners is the cell phone (Smyser, 2019), which brings with it issues of screen size and Wi-Fi connection among others. The learners were in diverse locations and, as was the case before, no funding meant that we could not use electronic course books for the lessons. Opportunities for developing learners' reading and writing skills were therefore significantly impacted.

\section{The response}

With these challenges in mind, we redesigned and developed the courses as The Online English Café, a programme for 30 hours of synchronous language instruction: one hour three times a week using Zoom. Adding 'café' to the title was a way to highlight that the lesson topics would be things people often talk about when they meet at cafés and that we speak and listen to others in a café conversation - as opposed to reading or writing, which would be more difficult to practise with the refugee learners in this context. The speaking and listening focus was supported using a lexical syllabus, which emphasises 'a common core of notions/functions, useful for all communicative goals' (Robinson, 2009, p.297), and which also affords flexibility in sequencing. Using Zoom meant that learners could receive one stable link to access their course without being obliged to create a new account and could attend from any location using only their first names. 
Two rounds of Online English Café classes were provided with volunteer teachers leading five cohorts each time, reaching over 50 learners. Class attendance occurred through a combination of individual cell phone use and, at the refugee centres, multiple learners using a shared laptop. Both ways worked well but each had their constraints; very small screens as a primary learning tool in the former case and seating at a distance from the screen in the latter. While some learners never missed a lesson, attendance did fluctuate due the highly changeable day-to-day context of the refugees. Additionally, learners' limited language level coupled with small screen size meant that it was not effective to have learners try to use the annotation tools in Zoom or type in the chat box, for example. The speaking and listening focus did help overcome the issue of screen size but impacted learner agency in the case of multiple learners sharing one laptop, where it is not feasible for each one to come to the laptop and input written answers from a practical standpoint or from the point of view of Covid-19 restrictions. Regarding learning resources in a resource-disadvantaged context, all the materials were either originally created or curated from open educational resources (OERs) or other free online resources, such as YouTube videos. Overall, the GCR, learners, and teachers all had positive reactions to the courses, which provided regular opportunities for cross-cultural exchange. In fact, one volunteer teacher commented, 'I'm not just teaching. l'm being taught'.

\section{Recommendations}

There are several recommendations to share from the Online English Café experience. One is to provide teacher training for the instructors. Being familiar with online tools from a learner's perspective is different to using the tools as a teacher. In our case, specific training on using the Annotate tools in Zoom was helpful.

Secondly, design learning with a small screen size in mind. This means text on slides should be large, and teachers should know how to use browser tools to enlarge an entire website to make text bigger for both cell phone and laptop viewing. Consider using OERs, for example, from the British Council (https://learnenglish.britishcouncil.org/) or American English (www.americanenglish.state.gov). OERs work to reduce inequalities stemming from access to 
information (Jones and Bridges, 2016). Many learners lack access to published materials such as course books and to devices that are effective for learning. Asylum seekers and other learners may be reluctant to expand their digital footprint. Therefore, it is important to create a learning environment that increases access and respects privacy.

Perhaps most importantly, leverage the benefits of being online to expand access to learning. Online delivery enabled us to reach greater numbers of learners in multiple locations in refugee camps as well as learners in a shelter for unaccompanied minors. We plan to continue the Online English Café even when restrictions are lifted while also broadening our in-person classes for families and school-age children. Thus, we can provide opportunities for learners beyond Covid-19 and beyond classroom borders.

\section{References}

Hodges, C., Moore, S., Lockee, B., Trust, T. and Bond, A. (2020) 'The difference between emergency remote teaching and online learning', EDUCAUSE Review, 27 March. Available at: https://er.educause.edu/articles/2020/3/the-difference-betweenemergency-remote-teaching-and-online-learning (Accessed: 28 July 2020).

Jones, M. and Bridges, R. (2016) 'Equity, access, and the digital divide in learning technologies: historical antecedents, current issues, and future trends', in Rushby, N. and Surry, D. (eds.) The Wiley handbook of learning technology. Chichester: Wiley Blackwell, pp.330-334.

Robinson, P. (2009) 'Syllabus design', in Long, M. and Doughty, C. (eds.) Handbook of language teaching. Malden, MA: Wiley Blackwell, pp.294-310.

Smyser, H. (2019) 'Adaptation of conventional technologies with refugee language learners: an overview of possibilities', in Sengupta, E. and Blessinger, P. (eds.) Language, teaching, and pedagogy for refugee education. Bingley: Emerald Publishing Limited, pp.125-139. 


\section{Author details}

Susan Stetson-Tiligadas has over 20 years of language teaching experience in Europe and the US and currently teaches in the EAP and MA in TESOL programmes at Deree - The American College of Greece. She holds a doctorate in Education with a specialisation in Instructional Design for Online Learning. Her research interests are in learner motivation, cognitive load, and teacher training.

Jane Mandalios teaches undergraduate and graduate Applied Linguistics at Deree - The American College of Greece. She has also taught at tertiary level in Libya and Dubai, teaching EFL/ESL, ESP, EAP, and Composition. Her professional interests include curriculum and materials development, assessment, translanguaging, and information literacy. She holds a doctorate in TESOL from Exeter University. 